\title{
UPAR and cathepsin B shRNA impedes TGF- $\beta 1$-driven proliferation and invasion of meningioma cells in a XIAP-dependent pathway
}

\author{
VR Gogineni ${ }^{1,3}$, R Gupta ${ }^{1,3}$, AK Nalla ${ }^{1}$, KK Velpula ${ }^{1}$ and JS Rao ${ }^{*, 1,2}$
}

Overexpression of transforming growth factor $\beta 1$ (TGF- $\beta 1$ ) has been linked to immune suppression, tumor angiogenesis, tumor cell migration, tumor cell survival, and tumor cell invasion in many cancers. In the present study, we found abundant expression of TGF- $\beta 1$ in the microenvironment of four different pathological types of meningioma tumors. TGF- $\beta 1$ induced invasion in malignant meningioma cells with an associated upregulation of urokinase-type plasminogen activator (UPA), uPAR, cathepsin B, and MMP-9, and this increase in proliferation was coupled with the expression of anti-apoptotic and pro-survival signaling molecules. In addition to the intense immunoreactivity of meningioma tumors to X-linked inhibitor to apoptosis (XIAP), its knockdown abolished the TGF- $\beta 1$-induced proliferation of these cells. The stimulation of XIAP expression and the activation of PSMAD-2 is mediated by phosphatidylinositol 3-kinase (PI3K)- and MEK-dependent pathways, and the addition of anti-TGF- $\beta 1$ antibodies prevented their expression with a consequent decrease in invasion. Bicistronic shRNA constructs targeting uPAR and cathepsin B (pUC) quenched TGF- $\beta 1$-driven invasion and survival of meningioma cells by downregulation of XIAP and pSMAD-2 expression. Animal models with intracranial tumors showed elevated levels of TGF- $\beta 1$, XIAP and pSMAD-2, and pUC treatment prevented this increased expression. Thus, targeted silencing of TGF- $\beta 1$-induced signaling by pUC in meningioma would provide new treatment approaches for management of meningioma.

Cell Death and Disease (2012) 3, e439; doi:10.1038/cddis.2012.170; published online 6 December 2012

Subject Category: Cancer

Meningioma is the second most common primary tumor of the central nervous system and arises from the arachnoidal 'cap' cells in the meninges. Meningiomas constitute $20 \%$ of all intracranial primary brain tumors and are more frequent in females. ${ }^{1}$ These tumors are usually benign in nature; however, they can be malignant because their continued growth impacts surrounding brain tissue. Dysregulation of apoptosis is an early event in the pathogenesis of meningiomas, and this inherent resistance to various pro-apoptotic signals may contribute to a tumor's resistance to current chemotherapeutic agents.

Transforming growth factor $\beta$ (TGF- $\beta$ ) is involved in physiological processes, such as wound healing, tissue development, and remodeling. TGF- $\beta$ has also been implicated in cancer, and it has been shown to regulate a number of events, such as angiogenesis, immune suppression, and cell migration. ${ }^{2-4}$ Most breast cancers express TGF- $\beta$, and TGF- $\beta 1$ is the most prominent form found in the plasma. ${ }^{5,6}$ Clinically, TGF- $\beta 1$ is often elevated in the plasma of breast cancer patients, and preclinically, several models have shown correlations among TGF- $\beta$ expression with increased tumorigenicity, invasiveness, and drug resistance. ${ }^{7,8}$ In mouse models of breast cancer, TGF- $\beta$ signaling has been shown to promote both lung and bone metastasis. ${ }^{9}$ TGF- $\beta$ cytokines may also inhibit proliferation and induce pro-apoptotic genes, such as the Bcl-2 superfamily members $B M F$ and $B I M$, as demonstrated in primary cultures of human fetal hepatocytes, but they also upregulate anti-apoptotic genes, such as $B C L-X L$ and $X I A P^{10}$ Thus, TGF- $\beta$ cytokines are pleiotropic and can exert tumorsuppressing as well as tumor-promoting effects. It has been shown that TGF- $\beta$ signaling through mitogen-activated protein kinase, c-Jun- $\mathrm{NH}_{2}$-kinase, p38, phosphatidylinositol 3-kinase (PI3K), and G-proteins may be responsible for some of the oncogenic effects in late-stage tumorigenesis. ${ }^{11}$ It is believed that these SMAD and non-SMAD signaling pathways contribute to the pro-oncogenic effect of TGF- $\beta$ in late-stage tumors by promoting the epithelial-mesenchymal transition, migration, angiogenesis, proliferation, and immune suppression.

\footnotetext{
${ }^{1}$ Department of Cancer Biology \& Pharmacology, University of Illinois College of Medicine at Peoria, Peoria, IL, USA and ${ }^{2}$ Department of Neurosurgery, University of Illinois College of Medicine at Peoria, Peoria, IL, USA

${ }^{*}$ Corresponding author: JS Rao, Department of Cancer Biology \& Pharmacology, University of Illinois College of Medicine at Peoria, One Illini Drive, Peoria, IL 61605, USA. Tel: +309 671 3445; Fax: +309 671 3442; E-mail: jsrao@ @uic.edu

${ }^{3}$ These authors contributed equally to this work.

Keywords: meningioma; TGF- $\beta 1$; XIAP; shRNA; UPAR and cathepsin B

Abbreviations: BCL-XL, B-cell lymphoma-extra large; Cdc42, Cell Division Control protein 42 homolog; CMV, Cytomegalovirus; DAB, 3,3'-diaminobenzidine or diaminobenzidine; DMEM, Dulbecco's modified Eagle medium; DTT, Dithiothreitol; EDTA, Ethylenediaminetetraacetic acid; ERK, Extracellular signal-regulated kinases; GAPDH, Glyceraldehyde 3-phosphate dehydrogenase; HRP, Horse raddish peroxidase; MMP, Matrix metalloproteinase; PBS, Phosphate-buffered saline; RNAi, RNA interference; shRNA, Short hairpin RNA; SV, Scrambled vector; TGF, Transforming growth factor; uPA, Urokinase plasminogen activator; uPAR, Urokinase plasminogen activator receptor; XIAP, X-linked inhibitor of apoptosis

Received 28.2.12; revised 21.9.12; accepted 09.10.12; Edited by P Salomoni
} 
Activation of receptor-bound, urokinase-type plasminogen activator (UPA) on the cell surface seems to play an important role in cancer cell invasion and metastasis. ${ }^{12}$ Expression of both UPA and UPAR correlates with an invasive cancer cell phenotype and poor prognosis. ${ }^{13}$ Expression of proteolytic parameters of the urokinase-type plasminogen activator system (UPA, UPAR) and cathepsin B have been proven to be independent prognostic parameters in cancer. For colon cancer, a high UPAR level portends a low 5-year survival rate. ${ }^{14}$ It has been shown that the UPAR protein is inducible by TGF $-\beta .{ }^{15}$ Our investigation uses this approach to examine the therapeutic significance of RNAi-mediated simultaneous downregulation of these proteolytic networks on TGF- $\beta 1$ induced signaling in malignant meningiomas.

\section{Results}

Meningioma tumors express TGF- $\beta 1$. We conducted immunohistochemical analysis for TGF- $\beta 1$ on different types of formalin-fixed meningioma clinical tissue samples and found the presence of TGF- $\beta 1$ in more than $94 \%$ of malignant meningioma types (average score: 76/80) indicating that TGF- $\beta 1$ is present in the tumor microenvironment. Epithelialtype meningioma showed distribution of immunoreactivity throughout the tumor tissue (Figure 1a). The cells of fibrous meningioma are usually arranged in fascicles, and TGF- $\beta 1$ reactivity was seen along these fascicles of cells (Figure 1a). Mixed or transitional meningioma is mostly characterized by whorls of cells and varied cell types. We observed the presence of intense staining surrounding the whorls and diffused staining among the other sites of the tissues (Figure 1a). In atypical meningioma, which is characterized by invasive cells, we found strong reactivity for TGF- $\beta 1$ in the entire tumor section, indicating high expression (Figure 1a). Further analysis of patient's data revealed that malignant meningiomas showed greater than $92 \%$ positive reactivity to TGF- $\beta 1$ regardless of sex or type with more than half of the cases showing very strong reactivity (Figures $1 \mathrm{a}$ and $\mathrm{b}$ ). Next, we have tested and found the expression of TGF- $\beta 1$ at the protein level in IOMM-Lee and $\mathrm{CH} 157-\mathrm{MN}$ cells using western blotting (Figure 1c).

TGF- $\beta 1$ induces invasion in meningioma cells. To observe dose-dependent effects of TGF- $\beta 1$ on cellular invasion and to correlate our observations with the role of TGF- $\beta 1$ in meningioma cell invasiveness, we performed Matrigel invasion assays. We observed that the effect of TGF- $\beta 1$ on invasion was dose dependent at TGF- $\beta 1$ concentrations of $10-50 \mathrm{ng} / \mathrm{ml}$, with a positive response until a dose of $30 \mathrm{ng} / \mathrm{ml}$ and a decrement upon further increase in dosage (Figure 2a). Subsequently, we examined the effect of TGF- $\beta 1$ on invasive molecules in meningioma cells. We observed peaks of UPA, MMP-2, and MMP-9 expression in response to TGF- $\beta 1$ at a concentration of $30 \mathrm{ng} / \mathrm{ml}$ as compared with the unstimulated cells (Figure $2 \mathrm{~b}$ ). IOMMLee cells showed a significant increase of uPA (3.1-fold), a

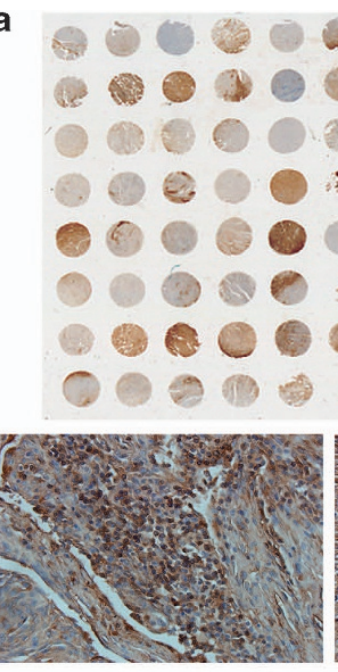

Epithelial

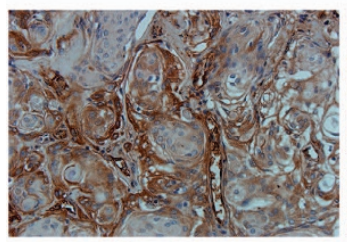

Mixed
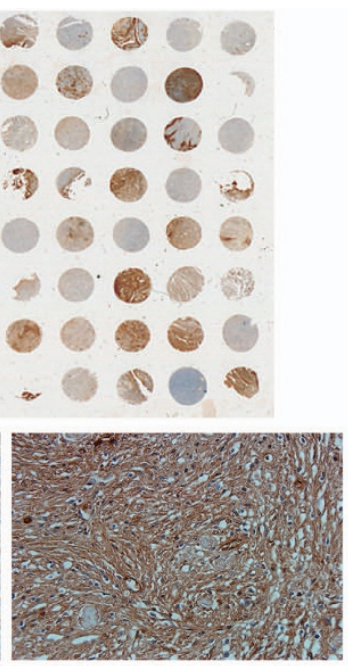

Fibrous

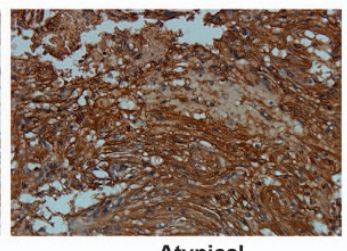

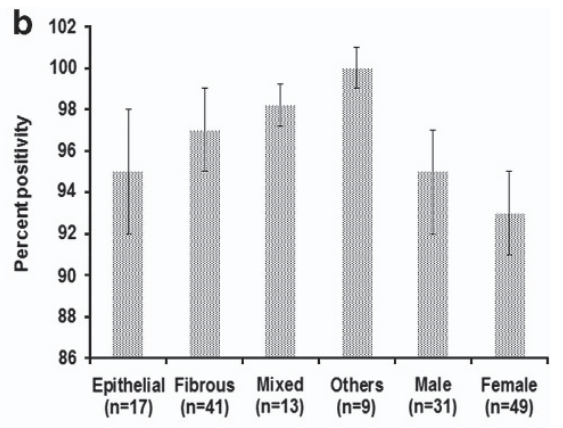

C

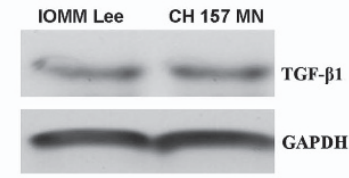

Atypical

Figure 1 Meningioma tumors express TGF- $\beta 1$. (a) Immunohistochemical analysis for TGF- $\beta 1$ was performed on the tissue microarrays of clinical meningioma samples. Representative images of whole array and different meningioma types $(\times 400)$ are shown. (b) Immunoreactivity for TGF- $\beta 1$ was plotted as percent positivity under different categories. Scoring was made for the reactivity as negative, less reactive, and highly reactive. (Others; atypical $(n=2)$, psammomatous $(n=2)$, microcapsule $(n=2)$, chordoid $(n=1)$, sparse $(n=1)$, and papillary $(n=1))$. Each picture or value is a representative or mean of three independent arrays. (c) IOMM-Lee and CH157-MN cell lysates were subjected to immunoblotting for TGF- $\beta 1$. GAPDH served as loading control. Each blot is representative of three independent experiments 
a
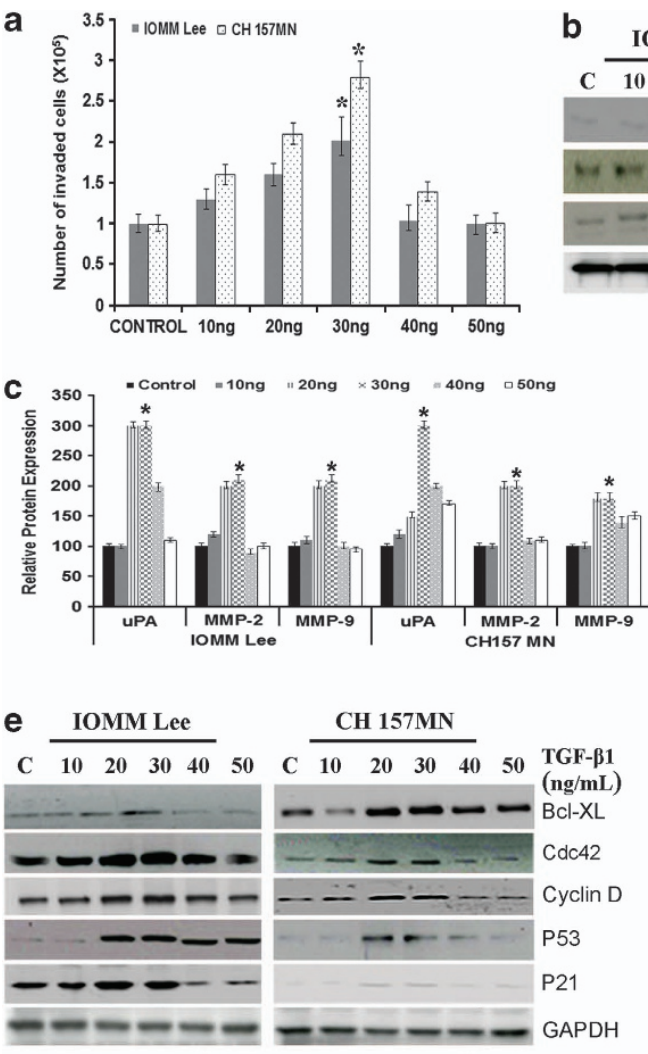

b

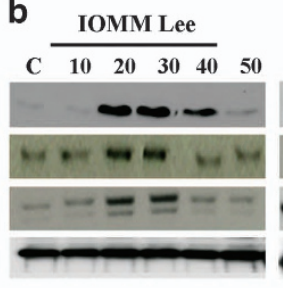

CH 157MN $\begin{array}{lllllll}\text { C } & 10 & 20 & 30 & 40 & 50 & \text { TGF- } \beta 1(n g / m L)\end{array}$ $-\infty-$ uPA

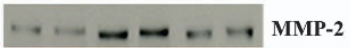

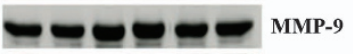
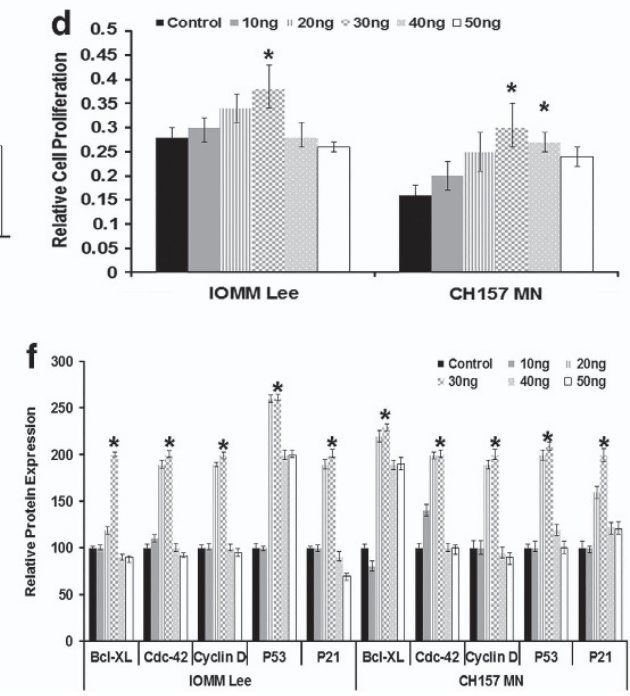

Figure 2 TGF- $\beta 1$ promotes cellular proliferation of meningioma cells in a dose-dependent manner. (a) IOMM-Lee and CH157-MN cells were grown to $90 \%$ confluence and then stimulated with TGF- $\beta 1$ at various doses for $24 \mathrm{~h}$. Cells were trypsinized and $0.4 \times 10^{5}$ cells were allowed to invade Matrigel-coated transwell inserts for $24 \mathrm{~h}$ at $37^{\circ} \mathrm{C}$. Then, the cells were fixed and stained. Invaded cells were photographed under a light microscope and the number of invaded cells was plotted against the dose of TGF$\beta 1$ (Columns: mean, bar: \pm S.D.; $n=3$ ). (b) Cell lysates from IOMM-Lee and CH157-MN cells that were treated with the indicated doses of TGF- $\beta 1$ for $48 \mathrm{~h}$ were subjected to western blot analysis for the detection of uPA, MMP-2, and MMP-9 using specific antibodies. GAPDH served as a loading control. Each blot is indicative of three independent experiments. (c) The band intensities from each blot were quantified using ImageJ software (National Institutes of Health, Bethesda, MD, USA) and relative expression was plotted. Columns represent mean \pm S.D. of three independent experiments. ${ }^{*} P<0.05$, significant difference from control without treatment. (d) Cell proliferation of meningioma cells that were treated with the indicated doses of TGF- $\beta 1$ for $72 \mathrm{~h}$ was measured using BrdU (colorimetric) kits. Data shown are mean \pm S.D. from three different experiments. ${ }^{*} P<0.05$, significant difference from control without treatment. (e) Cell lysates from IOMM-Lee and CH157-MN cells that were treated with specified doses of TGF- $\beta 1$ for $48 \mathrm{~h}$ were subjected to western blotting for the detection of Bcl-XL, Cdc42, Cyclin D, P53 and P21 using specific antibodies. GAPDH served as a loading control. Each blot is indicative of three independent experiments. (f) The band intensities from each blot were quantified using ImageJ software, and the relative expression was plotted. Columns represent mean \pm S.D. of three independent experiments. ${ }^{*} P<0.05$, significant difference from control without treatment

MMP-2 (2.0-fold), and MMP-9 (2.1-fold). The expression of these molecules among $\mathrm{CH} 157-\mathrm{MN}$ cells was comparable, showing a 3.0-fold increase in uPA levels and a 2.0-fold increase in MMP-2 levels (Figures $2 b$ and $c$ ); there was a slight but significant increase of MMP-9 protein (1.8-fold) in $\mathrm{CH} 157-\mathrm{MN}$ cells (Figures $2 \mathrm{~b}$ and $\mathrm{c}$ ). Though, a decrease in the expression patterns of these molecules was observed at higher concentrations of TGF- $\beta 1$ treatment, the levels were found to be comparable to those of the respective untreated cells (Figures $2 \mathrm{~b}$ and $\mathrm{c}$ ). Conversely, astrocytes treated with different concentrations of TGF- $\beta 1$ did not show any significant change in the expression of UPA, MMP-2, and MMP-9 molecules (Supplementary Figure 1)

TGF- $\beta 1$ promotes cellular proliferation in cultured meningioma cells in a dose-dependent manner. To observe the effect of TGF- $\beta 1$ on meningioma cell growth, we performed the BrdU proliferation assay. Not surprisingly, a dose-dependent effect on cell proliferation was observed in both cell lines with a maximum increase at $30 \mathrm{ng} / \mathrm{ml}$. The increase was significant, with IOMM-Lee cells showing a 1.4fold increase and $\mathrm{CH} 157-\mathrm{MN}$ cells showing a 2-fold increase compared with the respective untreated cells (Figure $2 d$ ). In contrast to CH157-MN cells, IOMM-Lee cells showed diminished proliferation at higher doses of TGF- $\beta 1$ upon comparison with unstimulated cells (Figure 2d). Next, we examined the effect of TGF- $\beta 1$ on anti-apoptotic and proproliferative molecules in meningioma cells. We observed $\mathrm{Bcl}-\mathrm{XL}, \mathrm{Cdc} 42$, and cyclin-D expression in meningioma cells incubated with TGF- $\beta 1$ at various concentrations for $24 \mathrm{~h}$. Similar to invasive molecules, we found the maximum response at $30 \mathrm{ng} / \mathrm{ml}$ of TGF- $\beta 1$ (Figure $2 \mathrm{~d}$ ). A significant increase of more than 1.5-fold increase was seen in all the molecules in both cell lines (IOMM-Lee: Bcl-XL, 1.5-fold; 
Cdc42, 1.5-fold; cyclin-D, 1.8-fold; CH157-MN: Bcl-XL, 2fold; Cdc42, 1.5-fold; cyclin-D, 2-fold) (Figures 2e and f). Surprisingly, we observed significantly enhanced expression of p53 and p21 at $30 \mathrm{ng} / \mathrm{ml}$ of TGF- $\beta 1$ (IOMM-Lee: > 2.0-fold; CH157-MN: >2.1-fold), which is in accordance with our earlier study demonstrating the anti-apoptotic role of p53 and its downstream molecules in meningiomas (Figures $2 \mathrm{e}$ and $\mathrm{f}$ ).

TGF- $\beta 1$ signaling regulates XIAP gene expression in meningioma cells. Given that $X$-linked inhibitor of apoptosis protein (XIAP) is a vital effector molecule in a SMADdependent manner for the tumor-promoting function of TGF$\beta 1$ in cancer cells, ${ }^{16}$ we investigated its role in meningioma cells. We observed an increase in expression of XIAP and pSMAD-2 among the TGF- $\beta 1$-treated meningioma cells at various concentrations. Maximum expression/activation of these proteins was seen in $30 \mathrm{ng} / \mathrm{ml}$ treatment groups, whereas expression was adversely affected at higher concentrations (Figure 3a). The increase of XIAP expression and SMAD-2 phosphorylation was found to be greater than 1.8-fold in both cell lines tested (Figures $3 a$ and b). To establish a causal role for these molecules in TGF- $\beta 1$ signaling, we performed function-blocking experiments.
Blockade of TGF- $\beta 1$ signaling via neutralizing antibodies significantly affected the expression of XIAP and phosphorylation of (SMAD-2) in both cell lines (Figure 3c). Further, we extended our function-blocking studies to determine the invasiveness of meningioma cells. As anticipated, neutralizing antibodies quenched the TGF- $\beta 1$ (30 ng/ml)-induced invasion in both cell lines (Figure $3 d$ ). In subsequent experiments, we used specific inhibitors that block PI3K and ERK pathways to find their role in TGF- $\beta 1$-induced signaling. We observed a partial decrease of XIAP expression and SMAD-2 phosphorylation in both inhibitor experiments, suggesting multiple pathways are activated to regulate signaling (Figure $3 \mathrm{e}$ ). Although the effect of inhibitors was significant in both cell lines, CH157-MN cells had a better response at the tested concentrations (Figures $3 e$ and f).

Knockdown of XIAP abolishes TGF- $\beta$ 1-driven cell proliferation. After results showed consistent modulation of XIAP, we questioned whether its role in TGF- $\beta 1$ signaling is supplementary or critical. Consequently, we initially measured the expression of XIAP in tumor sections in which we already noted TGF- $\beta 1$ expression. We found immunoreactivity to XIAP in all the samples that were positive for
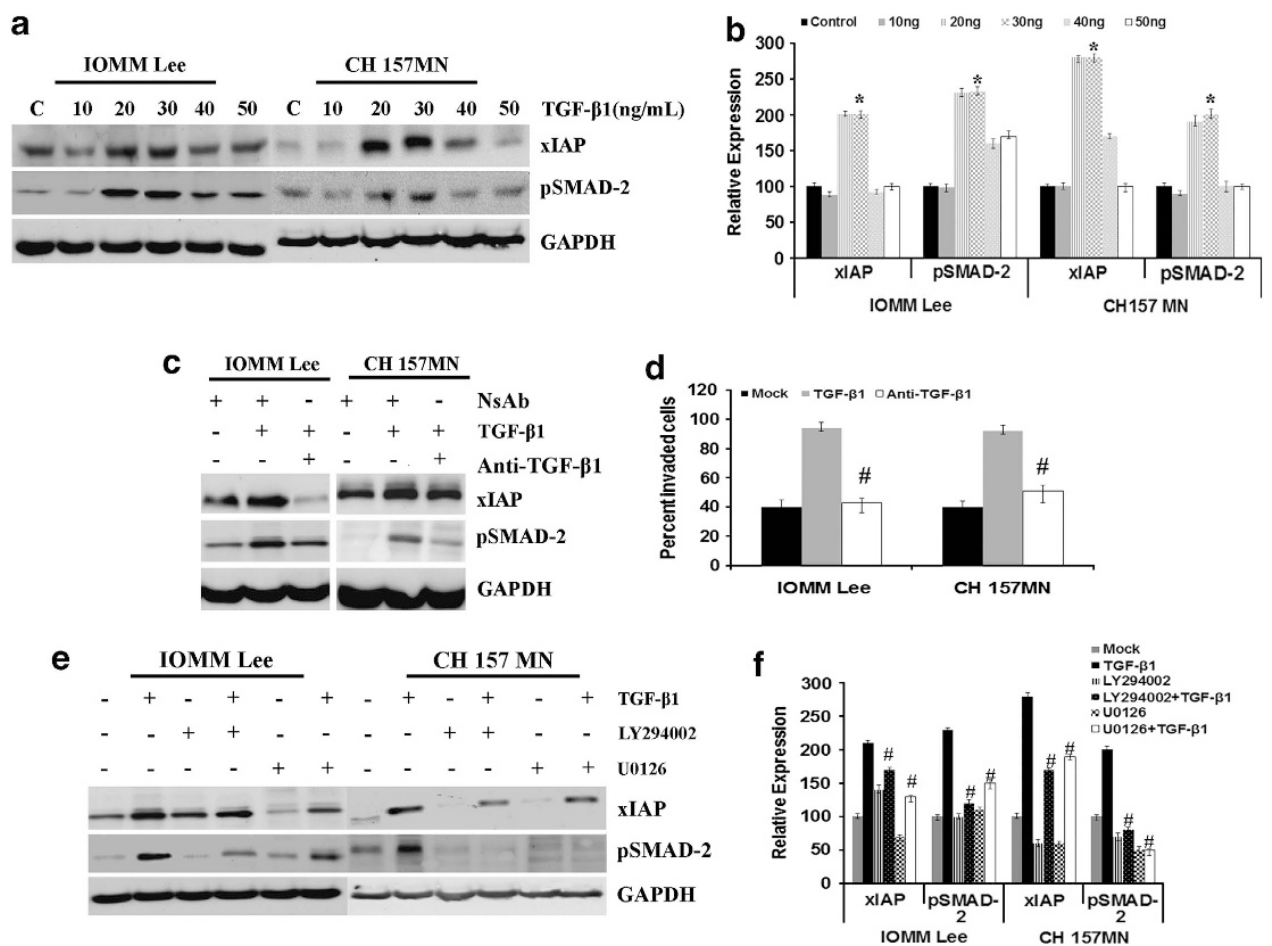

Figure 3 TGF- $\beta 1$ signaling regulates XIAP gene expression in meningioma cells. (a) Cell lysates from IOMM-Lee and CH157-MN cells that were treated with specified doses of TGF- $\beta 1$ were subjected to western blotting for the detection of XIAP, SMAD-2, and pSMAD-2 using specific antibodies. GAPDH served as a loading control. Each blot is indicative of three independent experiments. (b) Band intensities from each blot were quantified using ImageJ software and the relative expression was plotted. Columns represent mean \pm S.D. of three independent experiments. ${ }^{\star} P<0.05$, significant difference from control without treatment. (c) IOMM-Lee and CH157-MN cells were grown to $90 \%$ confluence and then stimulated by TGF- $\beta 1(30 \mathrm{ng} / \mathrm{ml})$ in conjunction with anti-TGF- $\beta 1$ antibody or nonspecific lgG (NsAb) for $48 \mathrm{~h}(10 \mu \mathrm{g} / \mathrm{ml})$. Cell lysates were probed for XIAP and pSMAD-2. GAPDH served as a loading control. (d) For invasion assays, cell for $24 \mathrm{~h}$ were trypsinized and allowed to invade Matrigel-coated transwell inserts for further $24 \mathrm{~h}$ at $37^{\circ} \mathrm{C}$. Then, the cells were fixed and stained. Invaded cells were photographed under a light microscope and percent invaded cells were plotted. Columns: mean; bars: \pm S.D.; $n=3$; ${ }^{\#} P<0.05$ versus control. (e) IOMM-Lee and CH157-MN cells grown to $90 \%$ confluence were pre-treated with vehicle (mock), PI3K inhibitor (LY294002;10 $\mu \mathrm{M}$ ), or MEK1/2 inhibitor (U0126; $10 \mu \mathrm{M})$ for 30 min and then stimulated by TGF- $\beta 1(30 \mathrm{ng} / \mathrm{ml})$ as indicated. Cell lysates were probed for XIAP and pSMAD-2 after $48 \mathrm{~h}$ of treatment. GAPDH served as a loading control. (f) The band intensities were quantified with ImageJ software, and the relative protein expression was plotted. Each blot represents three independent experiments and each column designates mean \pm S.D. of three independent experiments. ${ }^{\#} P<0.05$, significant difference from TGF- $\beta 1$ stimulated group of cells 
TGF- $\beta 1$ expression (Figure $4 a$ ). Although all four types of meningiomas were positive for XIAP expression, the intensity of reactivity was greater in atypical meningiomas (Figure 4a). Next, we used shRNA constructs to knock down XIAP and analyzed the consequential effects. Our western blot analysis showed that XIAP levels were markedly diminished in shRNA-treated cells (Figures $4 \mathrm{~b}$ and c). Immunoprecipitation of whole-cell lysates with pSMAD-2 antibody and subsequent western blotting for XIAP revealed that $\mathrm{DSMAD}-2$ directly interacts with XIAP and follows XIAP expression patterns in these cells (Figure 4b). However, the SMAD-2 levels remained same in the whole-cell lysates of the treated cells (Figure $4 b$ ). We noticed a significant decrease of proliferation in cells transfected with shRNA constructs compared with scrambled vector constructs (Figure $4 d$ ). The decrement was evident in both cell lines, and the cell numbers in TGF$\beta 1$-induced cells transfected with shRNA were smaller in comparison even to controls, indicating an obligatory role of XIAP (Figure 4d). We also tested the potential effect of XIAP knockdown on the invasiveness of the cells. We observed a substantial decline in the percentages of shRNA-expressing invaded cells, and TGF- $\beta 1$-induced invasion was particularly adversely affected (Figure 4e). Further, TGF- $\beta 1$-induced cells treated with embelin (XIAP inhibitor) have shown inhibition of SMAD-2 phosphorylation validating the function of XIAP shRNA in these cells (Supplementary Figure 2).

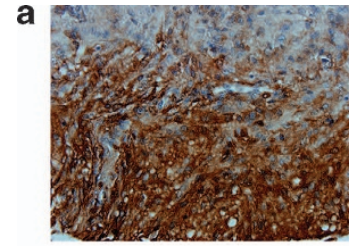
EPITHELIAL

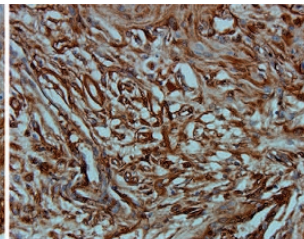

FIBROUS b

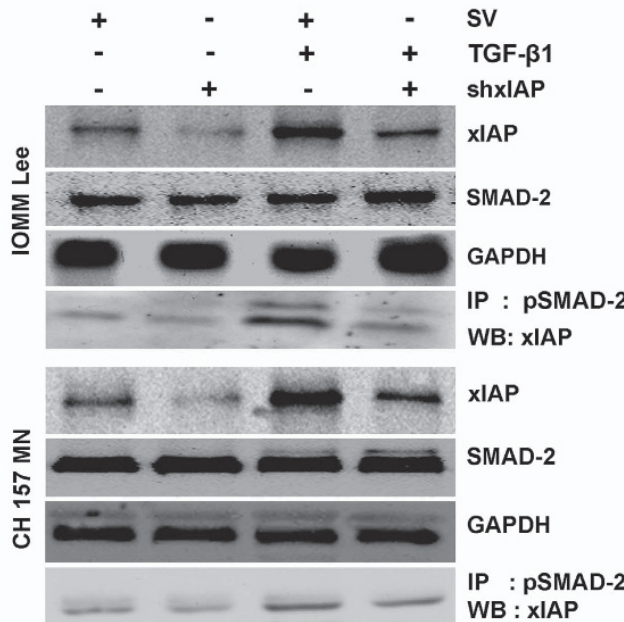

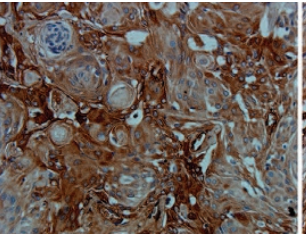

MIXED

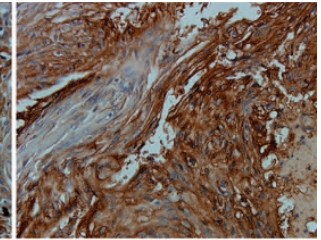

ATYPICAL

C

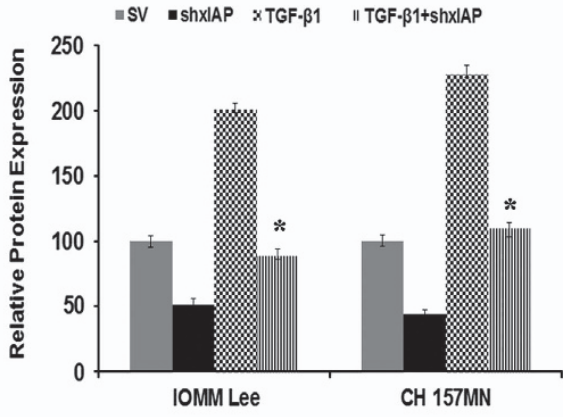

d

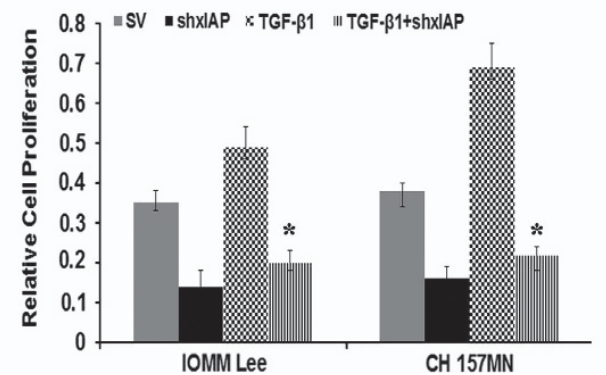

e

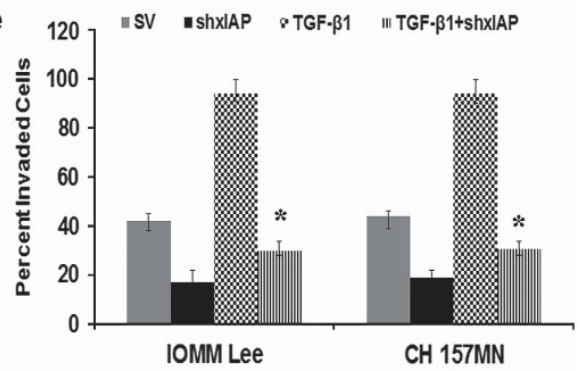

Figure 4 Knockdown of XIAP abolishes TGF- $\beta 1$-driven cell proliferation. (a) Immunohistochemical analysis for TGF- $\beta 1$ was performed on the tissue arrays of clinical meningioma samples. Representative images $(\times 400)$ of different meningioma types are shown. (b) Cells $\left(1.5 \times 10^{5}\right)$ seeded in a six-well plate were transfected with scrambled vector (SV) or shXIAP for $24 \mathrm{~h}$ and stimulated with TGF- $\beta 1$ for another $24 \mathrm{~h}$. Cell lysates were either probed for TGF- $\beta 1$ and GAPDH or immunoprecipitated with anti-pSMAD-2 antibody to analyze TGF- $\beta 1$ levels by western blotting. Each blot is a representative of three independent experiments. (c) The band intensities from each blot were quantified with ImageJ software and relative expression levels were plotted. Columns: mean; bars: \pm S.D.; $n=3 ;{ }^{*} P<0.05$ versus control. (d) Cells $\left(1.5 \times 10^{5}\right)$ seeded in a six-well plate were transfected with SV or shXIAP for $24 \mathrm{~h}$ and stimulated with TGF- $\beta 1$ for another $24 \mathrm{~h}$. Treated cells were analyzed for cell proliferation after another $48 \mathrm{~h}$ and relative cell proliferation was plotted. Columns: mean; bars: \pm S.D.; $n=3 ;{ }^{*} P<0.05$ versus control. (e) After $24 \mathrm{~h}$ of TGF- $\beta 1$ treatment, cells were allowed to invade Matrigel-coated transwell inserts for further $24 \mathrm{~h}$ at $37^{\circ} \mathrm{C}$ before fixing and staining. Then, the invaded cells were photographed under a light microscope and percent invaded cells were plotted. Each column designates mean \pm S.D. of three independent experiments. ${ }^{*} P<0.05$, significant difference from SV + TGF- $\beta 1$ 
Downregulation of UPAR and cathepsin B reduces TGF$\beta 1$-induced proliferation and invasion in meningioma. After our initial verification of TGF- $\beta 1$-mediated UPA, MMP2 , and MMP-9 upregulation with a concomitant increase in invasion of meningioma cells, we also observed an increase in the levels of UPAR and cathepsin B in TGF- $\beta 1$-mediated signaling (Figure $5 \mathrm{a}$ ). Transfection with shRNA constructs targeting UPAR and cathepsin B led to a marked decrease in their expression (Figure 5a). The decrease was more pronounced in TGF- $\beta 1$-treated cells compared with untreated cells (Figure $5 \mathrm{~b}$ ). We performed western blotting for XIAP and pSMAD-2 to confirm the upstream action of UPAR and cathepsin B in TGF- $\beta 1$-initiated signaling. The expression of XIAP and phosphorylation of SMAD-2 were substantially reduced by the silencing of UPAR and cathepsin $B$ in both cell lines (Figures $5 a$ and b). The consequences of uPAR and cathepsin B knockdown were also reflected in cellular proliferation. BrdU assays performed on shRNA-treated cells showed a discernible decrease in proliferation in both cell lines (Figure 5c), and the degree of decrease in proliferation was more evident and significant in TGF- $\beta 1$-treated cells. The invasive potential of IOMM-Lee and $\mathrm{CH} 157-\mathrm{MN}$ cells was also affected by uPAR and cathepsin B knockdown. Comparable to proliferation results, the percentage of invaded cells was also remarkably low in shRNA-treated cells. There was a 2 -fold reduction in shRNA-treated cells, whereas the decline was $>3$-fold in TGF- $\beta$ 1-treated, shRNA-expressing cells in comparison with cells treated with TGF- $\beta 1$ alone (Figures $5 \mathrm{c}$ and $\mathrm{d}$ ). Next, we assessed the expression profiles of other invasive and proliferative molecules that have been observed to change with TGF- $\beta 1$ signaling. Besides UPAR and cathepsin B, the protein levels of UPA, MMP-2, Cdc42, and cyclin-D were significantly lowered after shRNA treatments showing the reversal of TGF- $\beta 1$ induced signaling (Figures $5 e$ and $f$ ). a

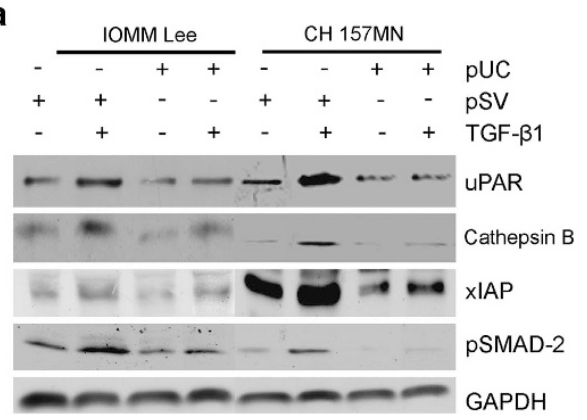

C

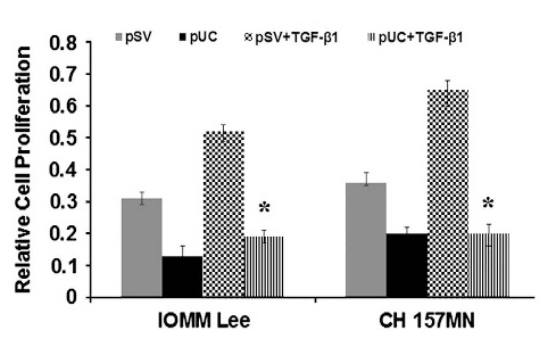

e

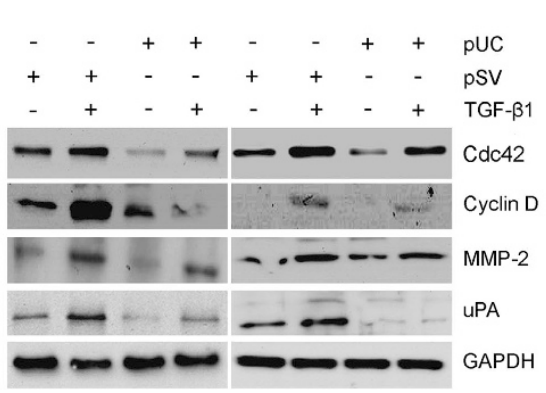

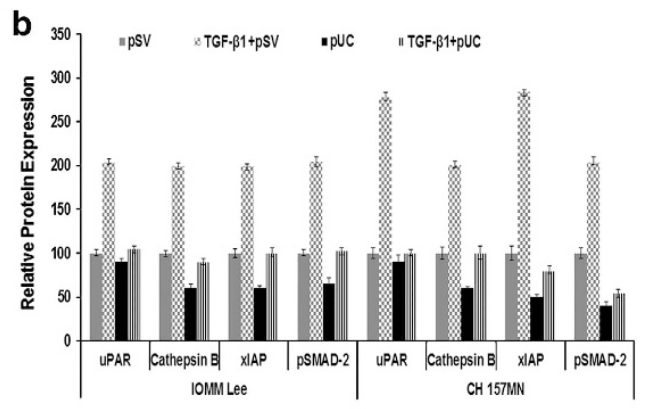

d

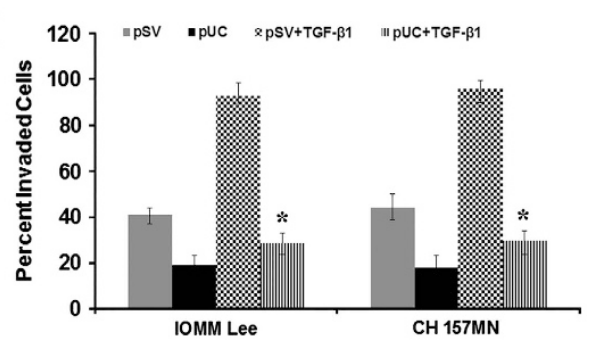

f

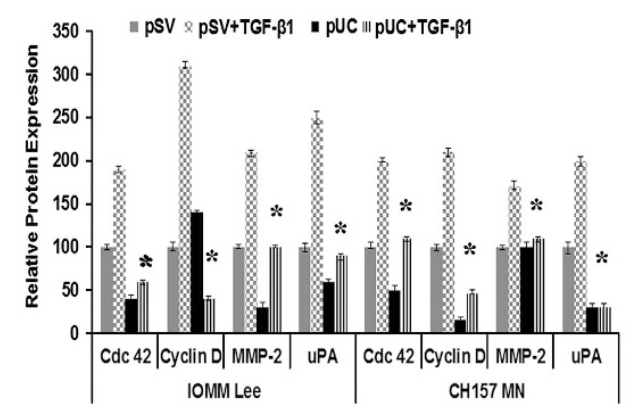

Figure 5 Downregulation of uPAR and cathepsin B decreases TGF- $\beta$ 1-induced proliferation and invasion in meningioma. (a) Cells $\left(1.5 \times 10^{5}\right)$ seeded in a six-well plate were transfected with scrambled vector (pSV) or pUC for $24 \mathrm{~h}$ and stimulated with TGF- $\beta 1$ for another $24 \mathrm{~h}$. Cell lysates were probed for uPAR, cathepsin B, XIAP, and pSMAD-2; GAPDH served as a loading control. Each blot is representative of three independent experiments. (b) The band intensities from each blot were quantified with ImageJ software and relative expression levels were plotted. Columns: mean; bars: \pm S.D.; $n=3$. (c) Treated cells were analyzed for cell proliferation after another $48 \mathrm{~h}$ and relative cell proliferation was plotted. Columns: mean; bars: \pm S.D.; $n=3$; ${ }^{*} P<0.05$ versus control. (d) After $24 \mathrm{~h}$ of TGF- $\beta 1$ treatment, cells were allowed to invade Matrigelcoated transwell inserts for further $24 \mathrm{~h}$ at $37^{\circ} \mathrm{C}$ before fixing and staining. Then, the invaded cells were photographed under a light microscope and the percent invaded cells were plotted. Columns: mean; bars: \pm S.D.; $n=3$; ${ }^{*} P<0.05$ versus control. (e) Lysates from $p S V$ - and pUC-treated cells were probed for Cdc42, cyclin-D, MMP-2, and uPA; GAPDH served as a loading control. Each blot is representative of three independent experiments. (f) The band intensities from each blot were quantified with ImageJ software and relative expression levels were plotted. Each column designates mean \pm S.D. of three independent experiments. ${ }^{*} P<0.05$, significant difference from SV + TGF- $\beta$ 
Knockdown of UPAR and cathepsin B decreases reduces TGF- $\beta 1$-induced signaling in vivo. The findings of our in vitro investigations were verified in orthotopic tumors models and meningioma clinical samples obtained postoperatively. The immunoreactivity of TGF- $\beta 1$ in orthotopic tumors initiated with IOMM-Lee and $\mathrm{CH} 157-\mathrm{MN}$ cells was remarkably high compared with normal brain sections. Despite the existence of TGF- $\beta 1$ in all the observed fields, intense staining was detected in the dense whorls of meningioma cells, whereas normal mouse brains showed very little or no reactivity (Figure 6a). In addition to morphological and behavioral recovery, concurrent knockdown of UPAR and cathepsin B led to a decrease in XIAP and pSMAD-2 expression in the brain sections of animals implanted with IOMM-Lee cells. We detected a marked change in the extent of their expression within 2 weeks of pUC infusion compared with pSV-treated sections (Figure 6b). Total tumor burden was also observed to be less than $50 \%$ in pUC-treated animals. To complement our immunohistochemical analysis, we made lysates of frozen clinical samples and mice brains and compared the expression of XIAP and PSMAD-2 with either normal human brain or normal mouse brain tissue. Clinical samples (18/20) and tumors formed in brains had elevated levels of TGF- $\beta 1$, $\mathrm{XIAP}$, and pSMAD-2 (Figure 6c). The relative expression of these proteins was significantly higher with a more than 2.5-fold increase in the tumors (Figure 6d).

\section{Discussion}

TGF- $\beta 1$ is a pleotropic regulatory polypeptide that performs contrasting roles either by inhibiting primary tumor a

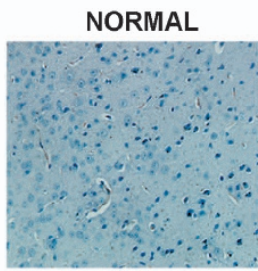

b

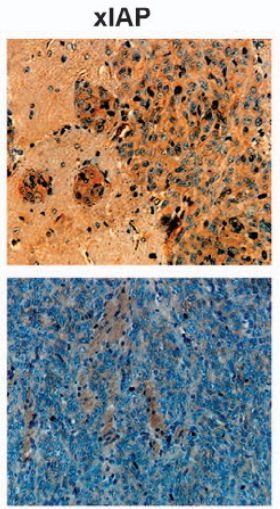

IOMM Lee

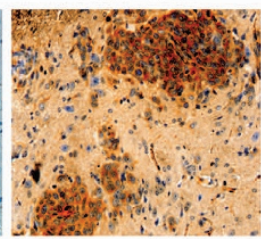

PSMAD-2
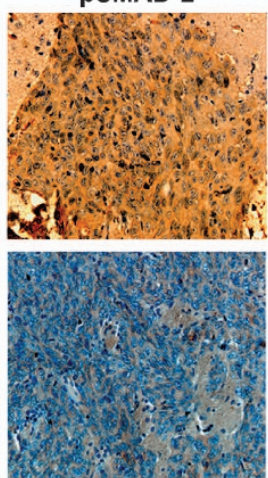

CH 157MN

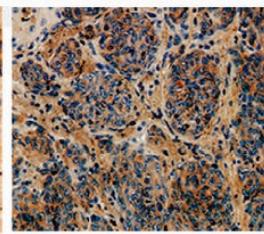

UPAR
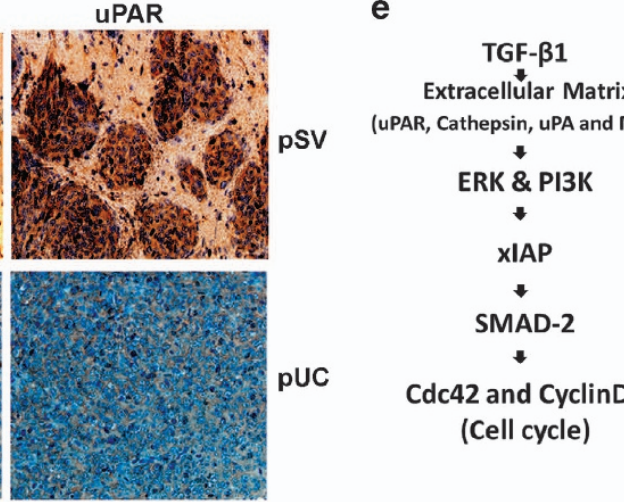

(UPAR, Cathepsin, UPA and MMPs)

t

ERK \& PI3K

เ

XIAP

+

SMAD-2

-

Cdc42 and CyclinD1

(Cell cycle) c

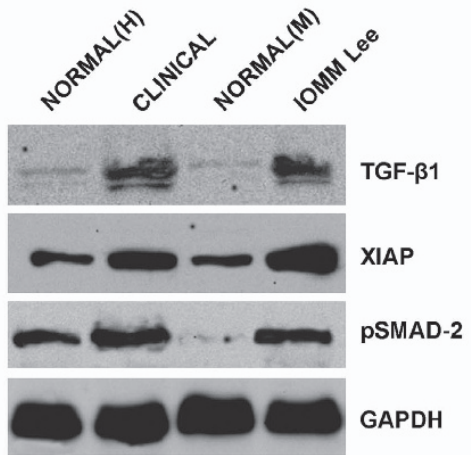

d

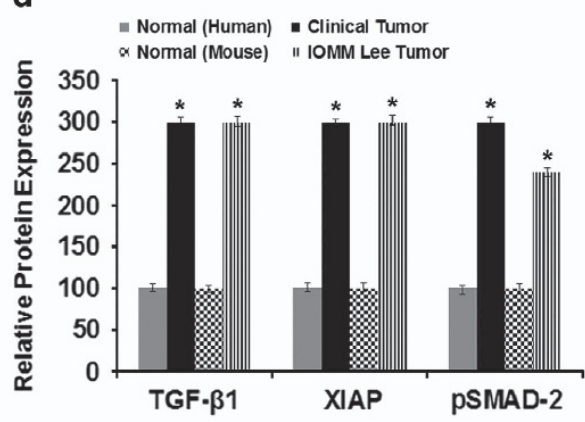

Figure 6 Knockdown of UPAR and cathepsin B reduces TGF- $\beta 1$-induced signaling in vivo. (a) Nude mice were intracranially implanted with IOMM-Lee and CH157-MN cells as described in Materials and Methods. Formalin-fixed brain sections were subjected to immunostaining with anti-TGF- $\beta 1$ antibody and nonspecific lgG (NslgG). Representative photomicrographs $(\times 200)$ are shown in comparison with normal mouse brain sections. (b) Nude mice intracranially implanted with IOMM-Lee cells were subsequently treated with pSV and pUC in different groups as described earlier. Formalin-fixed brain sections were checked for immunoreactivity with XIAP, pSMAD-2, and uPAR antibodies, and representative photomicrographs $(\times 200)$ are shown. (c) Frozen brain tissue lysates either from animal models or clinical samples were blot transferred and analyzed for TGF- $\beta 1$, XIAP, and pSMAD-2; GAPDH served as a loading control (H, human; M, mouse). (d) The band intensities from each blot were quantified with ImageJ software and relative expression levels were plotted. Each column designates mean \pm S.D. of three independent experiments. ${ }^{*} P<0.05$, significant difference from respective normal tissues. (e) Schematic representation of TGF- $\beta 1$ induced signaling in meningioma cells 
development and growth or by promoting tumor progression through a complex network of interdependent actions in late stages. ${ }^{17}$ The critical role of TGF- $\beta 1$ along with the effectors involved in signaling cascades offer potentially attractive therapeutic targets for cancer treatment. ${ }^{18}$ Although factors in the tumor microenvironment, such as fibroblasts, immune cells, and the extracellular matrix influence TGF- $\beta 1$ function, TGF- $\beta 1$ has been reported in the tumor microenvironments of prostate, breast, and brain cancers. ${ }^{19}$ Similar to various cancer types, in the present study, we have confirmed that human meningioma tumors contain TGF- $\beta 1$. As this is the first report demonstrating that meningioma tumors express TGF$\beta 1$, we hypothesized that it could be responsible for cell signaling, which promotes tumor progression.

In our in vitro studies, variation in invasive behavior of meningioma cells was evident at different concentrations of TGF- $\beta 1$ suggesting a complex role for TGF- $\beta 1$. Similar to our observations, bi-functional nature of TGF- $\beta 1$ in immunoglobulin production ${ }^{20}$ and biphasic functioning in fibroblast growth and migration ${ }^{21}$ has been reported. Even though TGF- $\beta 1$ possesses contrasting functions, we focused our inquiry on its tumor-promoting role in meningioma.

Degradation of the extracellular matrix marks the beginning of invasion and coupled to activation of proteolytic cascades. ${ }^{22}$ We observed a significant upsurge in UPA, MMP-2, and MMP-9 in treated cells, suggesting a causal role for TGF$\beta 1$ in the invasion of meningioma cells. In agreement with our interpretations, Ellenrieder et al. ${ }^{23}$ demonstrated that TGF$\beta 1$-induced invasion of pancreatic cancer cells is mediated by UPA and MMP-2. We noticed a significant induction of meningioma cell proliferation together with the expression of proteins that support cell cycle progression (e.g., Cdc42, cyclin-D) and antagonize apoptosis (e.g., XIAP, Bcl-XL) in TGF- $\beta 1$-treated cells. It has been reported that TGF- $\beta 1$ suppresses serum-deprived apoptosis in NIH3T3 cells ${ }^{24}$ and potentiates the survival of MCF10a cells. ${ }^{25}$ The induction of p53 and its downstream effector p21 at low doses of TGF- $\beta 1$ treatment further validates our earlier report on the possible oncogenic role of $p 53^{26}$ and previous observations that meningiomas display an accumulation of $p 53^{27}$ as well as dual functioning of $\mathrm{p} 21 .{ }^{28}$

There are numerous cascades through which TGF- $\beta 1$ initiates survival signaling in cancer cells. ${ }^{29}$ However, we found modulation of XIAP expression and SMAD-2 phosphorylation in meningioma cells. As XIAP and PSMAD-2 expression is regulated by TGF- $\beta 1,{ }^{16}$ we attempted to discern the pathways involved in TGF- $\beta 1$ signaling using inhibitor treatments. MEK and PI3K inhibitors quenched XIAP and PSMAD2 expression, thereby highlighting the direct involvement of these pathways. TGF- $\beta 1$ induced signaling via ERK phosphorylation in the collagen biosynthesis of mesengial cells and during NIH3T3 cell proliferation was also reported. ${ }^{24,30}$ On the other hand, PI3K-mediated TGF- $\beta 1$ signaling has not been widely reported. However, a recent study illustrates their participation in chronic myeloid leukemia pathogenesis. ${ }^{31} \mathrm{Akt}$ has been shown to phosphorylate and stabilize XIAP protein,, ${ }^{32}$ therefore, inhibition of PI3K/Akt activity could be the stability of the XIAP.

As XIAP is frequently overexpressed in different types of cancer, we studied its expression patterns in meningioma tissue sections and found very high incidence. In addition, XIAP shRNA abolished TGF- $\beta 1$-induced migration, whereas immunoprecipitation analysis performed in shRNA-treated cell lysates established SMAD-2-mediated activation of XIAP and the underlying physical interaction between them. TGF$\beta 1$ transduces signals through SMAD-dependent and independent pathways (reviewed in Dan et al. ${ }^{33}$ ). However, positive regulation of $X I A P$ gene expression in response to TGF- $\beta 1$ via SMAD-2 has been reported in uterine cancer cells. ${ }^{16}$ Our function-blocking experiments abrogated the invasive potential of meningioma cells, attributing the causal effect to TGF- $\beta 1$ with accompanied modulation of XIAP and pSMAD-2.

Abundant literature shows that pericellular proteases and their receptors are in close proximity with TGF- $\beta 1$ in the extracellular matrix or tumor microenvironment, and causally involved in remodeling of extracellular matrix. ${ }^{34}$ Moreover, UPA was the first protease shown to have TGF- $\beta 1$ activating capacity in presence of membrane-bound UPAR in peritoneal macrophages. ${ }^{35}$ In contrast, swift expression of MMP-2 and MMP-9 stimulated by TGF- $\beta 1$ has been shown to promote invasion and proliferation of pre-neoplastic breast epithelial cells. ${ }^{25}$ Cathepsin B and uPAR have key roles in the invasive and metastatic potential of different cancer cells, including meningioma. ${ }^{36,37}$ Bearing these things in mind, we hypothesized that the concurrent downregulation of UPAR and cathepsin $B$ using a bicistronic shRNA construct may regulate TGF- $\beta 1$-induced XIAP expression in highly invasive human meningioma cancer cell lines. We found that the downregulation of UPAR and cathepsin B by pUC-inhibited TGF$\beta 1$-induced expression of XIAP and pSMAD-2 expression, consequently abolishing invasion and cellular proliferation in these cells. We also noticed a significant decrease of other proliferative and invasive molecules - which indicates an overall reduction in the aggressive characteristics-and eventual apoptosis. The presence of TGF- $\beta 1$ in orthotopic tumors formed by meningioma cells confirmed its bioavailability for progression of meningioma. Decreased levels of TGF- $\beta 1, \mathrm{XIAP}$, and pSMAD-2 in tumor lysates of pUC-treated animals are suggestive of their downstream function in meningioma progression. Based on the findings of our investigation, we propose a scheme of TGF- $\beta 1$ induced signaling with involvement of proteolytic system in meningioma cells with ERK, PI3K, XIAP, and SMAD-2 as downstream effectors influencing cell cycle (Figure 6e). In conclusion, these results suggest that the tumor-promoting role of TGF- $\beta 1$ in meningioma is mediated by XIAP in a SMAD-2, PI3K, and ERK pathway-dependent manner. The present study shows that the targeting of TGF- $\beta 1$-induced cellular proliferation and invasion using pUC may be a potential treatment for meningioma.

\section{Materials and Methods}

Ethics statement. The Institutional Animal Care and Use Committee of the University of Illinois College of Medicine at Peoria (Peoria, IL, USA) approved all surgical interventions and post-operative animal care.

Construction of siRNA-expressing plasmids. Bicistronic constructs expressing siRNA for UPAR/cathepsin B (pUC) were constructed using a pcDNA3 vector as described previously by our group, and all vectors were expressed under 
the control of a CMV promoter. ${ }^{38}$ For the scrambled vector control, we used a pcDNA3 vector with an imperfect sequence that does not form a perfect hairpin structure (pSV).

Clinical samples. Meningioma tissue arrays were purchased from US Biomax, Inc., Rockville, MD, USA. Clinical meningioma tissue samples and blood samples were obtained from the institutional tumor bank (University of Illinois College of Medicine).

Cell culture. We used the human meningioma IOMM-Lee and CH157-MN cell lines (kindly provided by Dr. lan E McCutcheon, University of Texas MD Anderson Cancer Center, Houston, TX, USA and Dr. Yancey Gillespie, University of Alabama at Birmingham, Birmingham, AL, USA, respectively). All cells were cultured in high glucose-containing Dulbecco's modified Eagle's medium (DMEM). Cultures were supplemented with $100 \mu \mathrm{g} / \mathrm{ml}$ streptomycin, $100 \mathrm{U} / \mathrm{ml}$ penicillin, and $10 \%$ fetal calf serum and maintained in a humidified atmosphere containing $5 \%$ $\mathrm{CO}_{2}$ at $37^{\circ} \mathrm{C}$. Cells were transfected, either alone or in the presence of TGF- $\beta 1$, with pSV, pUC, or shXIAP using Fugene reagent (Roche Applied Science, Madison, WI, USA) following the manufacturer's instructions. Transfected cells were maintained in serum-containing media for $48 \mathrm{~h}$. The primary antibodies used for this study were anti-uPAR (R\&D Systems, Minneapolis, MN, USA), cathepsin B, MMP-2, MMP-9, UPA, p53, BCL-XL, p21, XIAP, cyclin-D (Santa Cruz Biotechnology, Santa Cruz, CA, USA), Cdc42, pSMAD-2, and anti-GAPDH (Cell Signaling Technology, Danvers, MA, USA) along with HRP-conjugated secondary antibodies (Santa Cruz Biotechnology).

Western blot analysis. All meningioma cells were either stimulated with TGF- $\beta 1$ at various doses or transfected with bicistronic constructs (pSV, pUC) for $48 \mathrm{~h}$ and kept under $21 \% \mathrm{O}_{2}$. Cell extracts were prepared in ice-cold RIPA buffer $(50 \mathrm{mmol} / / \mathrm{Tris}-\mathrm{HCl}(\mathrm{pH} 7.4), 150 \mathrm{mmo} / / \mathrm{NaCl}, 1 \%$ IGEPAL, $1 \mathrm{mmol} / / \mathrm{EDTA}$, $0.25 \%$ sodium deoxycholate, $1 \mathrm{mmol} / /$ sodium fluoride, $1 \mathrm{mmol} / \mathrm{l}$ sodium orthovanadate, $0.5 \mathrm{mmol} / / \mathrm{PMSF}, 10 \mu \mathrm{g} / \mathrm{ml}$ aprotinin, $10 \mu \mathrm{g} / \mathrm{ml}$ leupeptin). The protein concentration in each extract was determined by BCA assay (SigmaAldrich, St. Louis, MO, USA). Cell extracts were subjected to SDS-PAGE, and proteins were transferred to nitrocellulose membranes and probed with primary antibodies $(1: 1000)$. Subsequently, they were probed with HRP-conjugated secondary antibodies $(1: 2000)$, and signals were detected using $E C L$ reagents on X-ray films.

Matrigel invasion assay. Meningioma cells were either stimulated with TGF- $\beta 1$ at various doses or transfected with bicistronic constructs (pSV, pUC) for $48 \mathrm{~h}$. Cells $\left(0.5 \times 10^{5}\right)$ were placed into Matrigel-coated transwell inserts (Fisher Scientific, Pittsburgh, PA, USA) with $8-\mu \mathrm{m}$ pore size. Cells were allowed to migrate through the Matrigel for $24 \mathrm{~h}$. Cells in the upper chamber were removed with a cotton swab. The cells that adhered on the outer surface of the transwell insert or had invaded through the Matrigel were fixed, stained with Hema-3 (Fisher Scientific), and counted under a light microscope as described previously. ${ }^{39}$

BrdU proliferation assay. All meningioma cells were either stimulated with TGF- $\beta 1$ at various doses or transfected with pSV, pUC or shXIAP for $72 \mathrm{~h}$. Cells were trypsinized, counted, and seeded at $2 \times 10^{4}$ cells per well in 96-well plates (12 replicates per group). Cellular proliferation was measured using cell proliferation ELISA, BrdU (colorimetric) kit as per the manufacturer's instructions (Roche, Indianapolis, IN, USA). Absorbance was measured on a microtiter plate reader (Model 680, Bio-Rad, Hercules, CA, USA) with a test wavelength of $370 \mathrm{~nm}$ and a reference wavelength of $492 \mathrm{~nm}$.

Immunoprecipitation. Meningioma cells were grown in 100-mm plates, transfected with $\mathrm{pSV}$ and XIAP siRNA either alone or in the presence of TGF- $\beta 1$, and lysed in $1 \mathrm{ml}$ of immunoprecipitation buffer for $30 \mathrm{~min}$ on ice with occasional swirling. A volume of $1 \mathrm{ml}$ of immunoprecipitation buffer lacking detergent was then added to each plate, and cells were scraped. We used the following immunoprecipitation buffer: $\pm 0.5 \%$ 3-[(3-cholamidopropyl) dimethylammonio]-1propanesulfonic acid, $150 \mathrm{mM} \mathrm{NaCl}, 50 \mathrm{mM}$ Tris-Hcl, $2 \mathrm{mM}$ EDTA, $2 \mathrm{mM}$ EGTA, $2 \mathrm{mM} \mathrm{Na}_{3} \mathrm{VO}_{4}, 2 \mu \mathrm{M}$ DTT, and protease inhibitor mixture. Next, cells were spun for 20-30 min at $20000 \times g$, and the supernatants were used. Antibodies for PSMAD 2 were added at a dilution of $1: 100$ to a total of $1 \mathrm{ml}$, and immunoprecipitations were performed at $4{ }^{\circ} \mathrm{C}$ overnight with constant mixing. A volume of $50-100 \mu$ l of protein $A$ or $G$ beads were added, and the solution was allowed to mix for $1-3 \mathrm{~h}$ at
$4{ }^{\circ} \mathrm{C}$. Immunoprecipitations were washed four times using the immunoprecipitation buffer and then brought up in $2 \times$ Laemli buffer for protein electrophoresis and western blot analysis.

Establishment and treatment of orthotopic intracranial tumors in athymic nude mice. Orthotopic tumors were established through intracranial injection of tumor cells into brains of athymic nude mice as described elsewhere. ${ }^{40}$ Six animals were used for each group. IOMM-Lee cells were grown in serum-supplemented DMEM media for 2 days and trypsinized. 100000 cells were injected into anesthetized nude mice ( $50 \mathrm{mg} / \mathrm{kg}$ ketamine, $10 \mathrm{mg} / \mathrm{kg}$ xylazine) using a stereotactic frame. The animals were maintained for 1 week to allow the tumors to develop and then divided into four groups with six animals in each group. Alzet mini-osmotic pumps (Durect Corporation, Cupertino, CA, USA) containing $150 \mu \mathrm{g}$ of plasmid at a concentration of $1.5 \mu \mathrm{g} / \mu \mathrm{l}$ were set up for each animal. The animals were treated in two groups: one treatment group received pSV and the other group was treated with pUC and allowed to grow for 3-4 weeks. Once the control group (SV treated) showed chronic symptoms, the animals were euthanized by cardiac perfusion using PBS followed by $10 \%$ phosphate-buffered formalin. The brains were removed and stored in 10\% phosphate-buffered formalin and embedded in paraffin as described previously. ${ }^{37}$

Immunohistochemistry. Immunohistochemical analysis for TGF- $\beta 1$ and XIAP was performed on the slide tissue microarrays (US Biomax) of clinical meningioma samples. Briefly, paraffin-embedded slides containing meningioma brain sections from meningioma groups were deparaffinized as per standard protocol. The sections were treated to inhibit endoperoxidase activity $\left(0.03 \% \mathrm{H}_{2} \mathrm{O}_{2}\right.$ and $0.1 \% \mathrm{NaN}_{3}$ in PBS), blocked with $1 \% \mathrm{BSA}$ in PBS and incubated with primary antibodies (1:100 dilution) at $4{ }^{\circ} \mathrm{C}$ overnight. The sections were then washed in PBS and incubated with appropriate HRP-conjugated secondary antibodies for $1 \mathrm{~h}$ at room temperature. After $1 \mathrm{~h}$, sections were washed in PBS and incubated in $D A B$ for $30 \mathrm{~min}$. The slides were further washed with sterile water and subjected to dehydration. After dehydration, the slides were stained with hematoxylin to visualize the nucleus, mounted, and observed under a light microscope.

\section{Conflict of Interest}

The authors declare no conflict of interest

Acknowledgements. We thank Shellee Abraham for manuscript preparation. We also thank Diana Meister and Sushma Jasti for manuscript review. This research was funded by NINDS NS061835 to Jasti S Rao.

\section{Disclaimer}

The contents are solely the responsibility of the authors and do not necessarily represent the official views of $\mathrm{NIH}$.

1. Louis DN, Scheithauer BW, Budka H, von Deimling A, Kepes JJ. Meningiomas pathology and genetics of tumours of the nervous system. In: Kleihues P, Cavenee WK (eds). World Health Organization Classification of Tumours. IARC Press: Lyon, 2000. pp 176-184.

2. Jeon SH, Chae BC, Kim HA, Seo GY, Seo DW, Chun GT et al. Mechanisms underlying TGF-beta1-induced expression of VEGF and Flk-1 in mouse macrophages and their implications for angiogenesis. J Leukoc Biol 2007; 81: 557-566.

3. Muraoka RS, Dumont N, Ritter CA, Dugger TC, Brantley DM, Chen J et al. Blockade of TGF-beta inhibits mammary tumor cell viability, migration, and metastases. J Clin Invest 2002; 109: 1551-1559.

4. Pepper MS. Transforming growth factor-beta: vasculogenesis, angiogenesis, and vessel wall integrity. Cytokine Growth Factor Rev 1997; 8: 21-43.

5. Ivanovic V, Demajo M, Krtolica K, Krajnovic M, Konstantinovic M, Baltic V et al. Elevated plasma TGF-beta1 levels correlate with decreased survival of metastatic breast cancer patients. Clin Chim Acta 2006; 371: 191-193.

6. Kajdaniuk D, Marek B, Swietochowska E, Ostrowska Z, Glogowska-Szelag J, Kos-Kudla B et al. Plasma transforming growth factor beta1 in breast cancer patients treated with CMF chemotherapy. J Clin Pharm Ther 2000; 25: 291-294.

7. Elliott RL, Blobe GC. Role of transforming growth factor beta in human cancer. J Clin Oncol 2005; 23: 2078-2093

8. Huang A, Jin H, Wright JA. Drug resistance and gene amplification potential regulated by transforming growth factor beta 1 gene expression. Cancer Res 1995; 55: 1758-1762.

9. Bandyopadhyay A, Agyin JK, Wang L, Tang Y, Lei X, Story BM et al. Inhibition of pulmonary and skeletal metastasis by a transforming growth factor-beta type I receptor kinase inhibitor. Cancer Res 2006; 66: 6714-6721. 
10. Caja L, Bertran E, Campbell J, Fausto N, Fabregat I. The transforming growth factor-beta (TGF-beta) mediates acquisition of a mesenchymal stem cell-like phenotype in human liver cells. J Cell Physiol 2011; 226: 1214-1223.

11. Wilkes MC, Mitchell H, Penheiter SG, Dore JJ, Suzuki K, Edens M et al. Transforming growth factor-beta activation of phosphatidylinositol 3-kinase is independent of Smad2 and Smad3 and regulates fibroblast responses via p21-activated kinase-2. Cancer Res 2005; 65: 10431-10440.

12. Mignatti $P$, Rifkin DB. Biology and biochemistry of proteinases in tumor invasion. Physiol Rev 1993; 73: 161-195.

13. Rabbani SA, Mazar AP. The role of the plasminogen activation system in angiogenesis and metastasis. Surg Oncol Clin N Am 2001; 10: 393-415.

14. Ganesh S, Sier CF, Heerding MM, Griffioen G, Lamers CB, Verspaget HW. Urokinase receptor and colorectal cancer survival. Lancet 1994; 344: 401-402.

15. Lund LR, Ellis V, Ronne E, Pyke C, Dano K. Transcriptional and post-transcriptional regulation of the receptor for urokinase-type plasminogen activator by cytokines and tumour promoters in the human lung carcinoma cell line A549. Biochem J 1995; 310: 345-352.

16. Van Themsche C, Chaudhry P, Leblanc V, Parent S, Asselin E. XIAP gene expression and function is regulated by autocrine and paracrine TGF-beta signaling. Mol Cancer 2010; 9: 216216.

17. Joshi $A, C a o D$. TGF-beta signaling, tumor microenvironment and tumor progression: the butterfly effect. Front Biosci 2010; 15: 180-194.

18. Kelly RJ, Morris JC. Transforming growth factor-beta: a target for cancer therapy. $\mathrm{J}$ Immunotoxicol 2010; 7: 15-26.

19. Bierie B, Moses HL. Tumour microenvironment: TGFbeta: the molecular Jekyll and Hyde of cancer. Nat Rev Cancer 2006; 6: 506-520.

20. McKarns SC, Letterio JJ, Kaminski NE. Concentration-dependent bifunctional effect of TGF-beta 1 on immunoglobulin production: a role for Smad3 in IgA production in vitro. Int Immunopharmacol 2003; 3: 1761-1774.

21. Cordeiro MF, Bhattacharya SS, Schultz GS, Khaw PT. TGF-beta1, -beta2, and -beta3 in vitro: biphasic effects on Tenon's fibroblast contraction, proliferation, and migration. Invest Ophthalmol Vis Sci 2000; 41: 756-763.

22. Rao JS. Molecular mechanisms of glioma invasiveness: the role of proteases. Nat Rev Cancer 2003; 3: 489-501.

23. Ellenrieder V, Hendler SF, Ruhland C, Boeck W, Adler G, Gress TM. TGF-beta-induced invasiveness of pancreatic cancer cells is mediated by matrix metalloproteinase-2 and the urokinase plasminogen activator system. Int J Cancer 2001; 93: 204-211.

24. Chen HH, Zhao S, Song JG. TGF-beta1 suppresses apoptosis via differential regulation of MAP kinases and ceramide production. Cell Death Differ 2003; 10: 516-527.

25. Kim ES, Kim MS, Moon A. TGF-beta-induced upregulation of MMP-2 and MMP-9 depends on p38 MAPK, but not ERK signaling in MCF10A human breast epithelial cells. Int J Oncol 2004; 25: 1375-1382.

26. Gupta R, Rao GV, Nalla AK, Chetty C, Klopfenstein JD, Tsung AJ et al. Oncogenic role of p53 is suppressed by si-RNA bicistronic construct of UPA, UPAR and cathepsin-B in meningiomas both in vitro and in vivo. Int $J$ Oncol 2011; 38: 973-983.
27. Ellison DW, Lunec J, Gallagher PJ, Steart PV, Jaros E, Gatter KC. Accumulation of wildtype p53 in meningiomas. Neuropathol Appl Neurobiol 1995; 21: 136-142.

28. Cmielova J, Rezacova M. p21Cip1/Waf1 protein and its function based on a subcellular localization [corrected]. J Cell Biochem 2011; 112: 3502-3506.

29. Leivonen SK, Kahari VM. Transforming growth factor-beta signaling in cancer invasion and metastasis. Int J Cancer 2007; 121: 2119-2124.

30. Hayashida T, Decaestecker M, Schnaper HW. Cross-talk between ERK MAP kinase and Smad signaling pathways enhances TGF-beta-dependent responses in human mesangial cells. FASEB J 2003; 17: 1576-1578.

31. Zhu X, Wang L, Zhang B, Li J, Dou X, Zhao RC. TGF-beta1-induced PI3K/Akt/NF-kappaB/ MMP9 signalling pathway is activated in Philadelphia chromosome-positive chronic myeloid leukaemia hemangioblasts. J Biochem 2011; 149: 405-414.

32. Derynck R, Zhang YE. Smad-dependent and Smad-independent pathways in TGF-beta family signalling. Nature 2003; 425: 577-584.

33. Dan HC, Sun M, Kaneko S, Feldman RI, Nicosia SV, Wang HG et al. Akt phosphorylation and stabilization of X-linked inhibitor of apoptosis protein (XIAP). J Biol Chem 2004; 279: 5405-5412.

34. ten Dijke P, Arthur HM. Extracellular control of TGFbeta signalling in vascular development and disease. Nat Rev Mol Cell Biol 2007; 8: 857-869.

35. Nunes I, Shapiro RL, Rifkin DB. Characterization of latent TGF-beta activation by murine peritoneal macrophages. J Immunol 1995; 155: 1450-1459.

36. Gondi CS, Lakka SS, Yanamandra N, Olivero WC, Dinh DH, Gujrati M et al. Adenovirusmediated expression of antisense urokinase plasminogen activator receptor and antisense cathepsin B inhibits tumor growth, invasion, and angiogenesis in gliomas. Cancer Res 2004; 64: 4069-4077.

37. Gupta R, Nalla AK, Gogineni VR, Chetty C, Bhoopathi P, Klopfenstein JD et al. uPAR/ cathepsin $B$ overexpression reverse angiogenesis by rescuing FAK phosphorylation in UPAR/cathepsin B down regulated meningioma. PLoS One 2011; 6: e17123.

38. Lakka SS, Gondi CS, Yanamandra N, Olivero WC, Dinh DH, Gujrati M et al. Inhibition of cathepsin B and MMP-9 gene expression in glioblastoma cell line via RNA interference reduces tumor cell invasion, tumor growth and angiogenesis. Oncogene 2004; 23: 4681-4689.

39. Gondi CS, Lakka SS, Yanamandra N, Siddique K, Dinh DH, Olivero WC et al. Expression of antisense UPAR and antisense UPA from a bicistronic adenoviral construct inhibits glioma cell invasion, tumor growth, and angiogenesis. Oncogene 2003; 22: 5967-5975.

40. McCutcheon IE, Friend KE, Gerdes TM, Zhang BM, Wildrick DM, Fuller GN. Intracranial injection of human meningioma cells in athymic mice: an orthotopic model for meningioma growth. J Neurosurg 2000; 92: 306-314.

Cell Death and Disease is an open-access journal published by Nature Publishing Group. This work is licensed under the Creative Commons Attribution-NonCommercial-No Derivative Works 3.0 Unported License. To view a copy of this license, visit http://creativecommons.org/licenses/by-nc-nd/3.0/

Supplementary Information accompanies the paper on Cell Death and Disease website (http://www.nature.com/cddis) 